\title{
EFFECTS OF PRODUCTIVE ACTIVITIES ON THE WATER QUALITY FOR HUMAN CONSUMPTION IN AN ANDEAN BASIN, A CASE STUDY
}

\author{
Diana Marcela RUIZ*, Juan Pablo MARTÍNEZ IDROBO, Juan Diego OTERO SARMIENTO \\ and Apolinar FIGUEROA CASAS
}

Grupo de Estudios Ambientales, Universidad del Cauca. Vicerrectoría de Investigaciones, Carrera 2 1A - 25, Popayán, Cauca, Colombia, C. P. 190003

*Autor para correspondencia: dianamruiz@unicauca.edu.co

(Received October 2015; accepted October 2016)

Key words: water pollution, agriculture, spatial crop distribution, biodiversity, drinking water

\begin{abstract}
Productive activities such as agriculture and livestock have transformed the Andean basins in South America. In accordance with this statement, the objective of this study was to assess the water quality of "Las Piedras" river located in an Andean basin with 6626 ha in Colombian Highlands. This study analyzed nutrient inputs from agricultural production, spatial crops distribution, human activities and their influence on the ecological state of the river. The evaluation integrated physicochemical and biological parameters in the indexes of water quality, pollution and the aquatic macroinvertebrates community. Results showed that aggregated crop fields occupy $25.2 \%$ in the basin and the biological water quality through the Biological Monitoring Working Party (BMWP) index denotes the presence of tolerant-pollution organisms, additionally the biodiversity was low (Shannon H'1.1). The water quality in the river satisfies the Colombian regulation criteria for human consumption, even higher concentrations of nutrients in the lower area with $2.20 \mathrm{mg} / \mathrm{L}$ nitrates and $1.49 \mathrm{mg} / \mathrm{L}$ of phosphates, besides the loss of nutrients by runoff, which was $2.57 \mathrm{mg} / \mathrm{L}$ nitrates in the middle area and $0.18 \mathrm{mg} / \mathrm{L}$ phosphates in the upper area. In this sense, the nutrient concentration input increases toward the lower area of the basin because of the crop distribution. The agricultural land use modified the hydrological ecosystem services by decreasing the basin water regulatory capacity and nutrients input to the main stream.
\end{abstract}

Palabras clave: contaminación hídrica, agricultura, distribución espacial de los cultivos, biodiversidad, agua potable

\section{RESUMEN}

Las actividades productivas como la agricultura y la ganadería han transformado las cuencas andinas de América del Sur. El objetivo de este estudio fue evaluar la calidad del agua en la cuenca del río Las Piedras (6626 ha), localizada en la alta montaña colombiana. Se analizaron los aportes de nutrientes a partir de la producción agrícola, distribución espacial de cultivos, actividades humanas y su influencia en el estado ecológico del río. La evaluación integró los parámetros físicos, químicos y biológicos en índices de calidad del agua, de contaminación y de macroinvertebrados acuáticos. Los resultados mostraron que los cultivos ocupan el $25.2 \%$ de la cuenca, la calidad biológica del agua según el 
índice del Grupo de Trabajo de Monitoreo Biológico (BMWP, por sus siglas en inglés) evidenció la presencia de organismos tolerantes a la contaminación y baja biodiversidad (Shannon H'1.1). La calidad del agua es apta para consumo humano según los estándares establecidos por la normatividad Colombiana. Sin embargo, se encontraron altas concentraciones de nutrientes en la zona baja del río con $2.20 \mathrm{mg} / \mathrm{L}$ de nitratos y $1.49 \mathrm{mg} / \mathrm{L}$ de fosfatos, adicionalmente los aportes de nutrientes en escorrentía superficial fueron de $2.57 \mathrm{mg} / \mathrm{L}$ de nitratos en la zona media y $0.18 \mathrm{mg} / \mathrm{L}$ de fosfatos en la zona alta. En este sentido, se observó que el ingreso de nutrientes aumenta hacia la zona baja de la cuenca debido a la distribución espacial de los cultivos. El uso agrícola del suelo modificó los servicios ecosistémicos hídricos por la disminución de la capacidad de regulación en la cuenca y el aporte de nutrientes al cauce principal.

\section{INTRODUCTION}

In Colombia, according to international policies, the integrated monitoring of water and soil quality promotes sustainability in basins regarding the conservation of environmental resources (IWMI 2007, MAVDT 2010). The analysis has focused on the physicochemical characteristics (IDEAM 2007, Bates et al. 2008), but these are not complemented by biological parameters to calculate quality and pollution indexes and support decision-making processes (Whitehead 2009, Muñoz et al. 2012).

These specific measurements of water quality do not reflect the interaction between anthropic activities and water pollution in the decline of ecosystem services (ES) in the Andean basins (Balthazar et al. 2015). The benthic communities' biomonitoring is suggested as a complementary alternative to the traditional techniques of water quality analysis because it incorporates the response to environmental conditions in the structure and function of their communities, which are sensitive to the agriculture management effects (Lock et al. 2011).

Some basin models have been widely used to estimate the impact of nutrient pollution from crop production to the water supplies in the Andean region. However, the control of water conditions has been an uncertain aspect to the crop spatial distribution and its impact on the water quality (Guo et al. 2014).

To obtain an integral approach, the multitemporal spatial analysis of land cover shows the transformation of landscapes and provides information to determine the alteration of ecosystem functions in the basin. These analyses generate indirect information about landscape functions. Due to their complexity, the land cover data can be used as a proxy for ecological assessments in natural areas (Balthazar et al. 2015). This information is relevant to recognize the influence of land management in Andean basins that comprises the endemic affectation of ES and the welfare of rural communities (Balvanera et al. 2012, Frank et al. 2012).

The spatial change of land cover provides information to understand the trends of occupation, degradation and biodiversity loss, as a result of the expansion of the agricultural lands and deforestation (Llausàs and Nogué 2012, Nagendra et al. 2013). Different land cover histories assess the effect of land use change on the erosion process. Additionally, changes in the area and crop yield distribution can relate to increases in runoff(Molina et al. 2012). Inputs of pollutants in different zones help to establish critical areas of land management.

Quantification of spatial patterns like aggregation and adjacency in land uses within different landscape units found along the basin, shows correlations between the dispersion of agricultural areas and the management techniques (Mouri et al. 2011, Salman et al. 2011). This determines the incidence of crop spatial distribution in river pollution.

From that perspective, this research approaches the integral techniques of water and soil analysis, linking physicochemical and biological variables through a multivariate analysis (Andrade and Stigter 2009). The objective was to generate a tool that assesses the spatial and temporal dynamics of the water quality in Andean basin areas, considering the influence of agricultural activities in water management.

\section{MATERIALS AND METHODS}

\section{Study area}

The Las Piedras river basin is located in the municipalities of Popayán and Totoró (Cauca -Colombia), situated between $76^{\circ} 31^{\prime} 10^{\prime \prime} \mathrm{W}-2^{\circ} 21^{\prime} 45^{\prime \prime} \mathrm{N}$ and $76^{\circ} 23^{\prime} 45^{\prime \prime} \mathrm{W}-2^{\circ} 25^{\prime} 40^{\prime \prime} \mathrm{N}$. Its extension is 6626 ha, the temperature ranges from $10.4^{\circ} \mathrm{C}$ in the upper area to $18.4^{\circ} \mathrm{C}$ in the lower area. The climatic zones are typically cold and temperate (1980 to 3820 masl), the topography is mountainous with steep, long and 


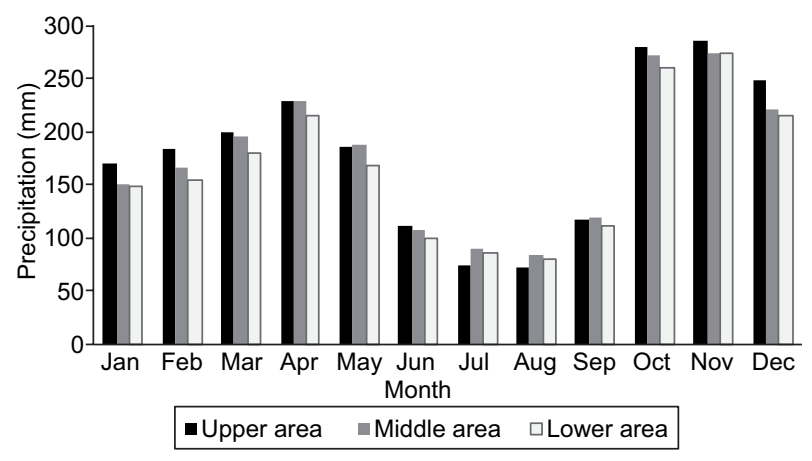

Fig. 1. Multiannual average monthly rainfall in Las Piedras river basin (1950-2010)

straight slopes in the middle and upper area, while in the lower area is flat and concave.

According to the multi-annual average monthly rainfall for the period of 1950 to 2010 (Fig. 1), the precipitation regimes in the basin were identified. The rainiest months (260 $\mathrm{mm}-285 \mathrm{~mm}$ ) were October and November, medium rainfall occurs between June and July (99 mm - $119 \mathrm{~mm}$ ), and low rainfall ( $72 \mathrm{~mm}$ $-89 \mathrm{~mm}$ ) during August and September. The annual rainfall average for 2014 was $135 \mathrm{~mm}$.

The soil is composed of volcanic ash; it is poorly structured and well drained with silty clay. It has low acidity ( $\mathrm{pH}$ ranges 5 to 5.9) and high aluminum saturation $(50-85 \%)$. The main land uses are forest with 1720 ha $(27 \%)$, pasture 3125 ha (52\%), and crops 267 ha (3 \%) according to Figueroa et al. (2012). In the basin there are peasants and indigenous communities from the reserves of Quintana and Puracé.

\section{Experimental set-up}

Three points were selected along the main stream to analyze water quality and surface runoff in the basin, covering the upper (3150 masl), middle (2550 masl) and lower (2050 masl) areas (Fig. 2). Selection criteria adhere to the land use distribution map, the analysis of basin morphometric and crop aggregations,



Fig. 2. Las Piedras basin study area and monitoring points 
which have been developed along the mainstream and parallel to the road in order to commercialize the products. For surface runoff analysis a rain simulator "under controlled conditions" was set up in order to produce fast, reliable, efficient, replaceable and costeffective data. The simulator trickled water droplets of about $2.75 \mathrm{~mm}$ in diameter, by means of hypodermic needle-like nozzles $(n=24)$, distributed in an area of $0.42 \mathrm{~m} \times 0.33 \mathrm{~m}$. This simulated rain had droplets with terminal velocities of around $4.0 \mathrm{~m} / \mathrm{s}$, and rain kinetic energy of $17.9 \mathrm{~J} / \mathrm{mm} / \mathrm{m}$ (Cobo 1998). The simulated rain intensity was calibrated according to climatic conditions in the region and the methodology proposed for andean soils (Otero et al. 2011). In this study, the time period chosen for the tests was $30 \mathrm{~min}$ according to the historical rainfall distribution series.

\section{Biological diversity}

The biological diversity was analyzed according to the variation of the alfa $(\alpha)$ and beta $(\beta)$ diversity: the Margalef index for specific richness and the Shannon Weiner index $\left(\mathrm{H}^{\prime}\right)$ to characterize species diversity in the epicontinental aquatic macroinvertebrate (EAM) community. The $\mathrm{H}^{\prime}$ index accounts for community structure in both abundance and evenness of the species. The relation between this indexes was evaluated by the linear regression model with the determination coefficient $\left(\mathrm{R}^{2}\right)$. The $\beta$ diversity analysis was studied with the Jaccard similarity coefficient.

\section{Water quality assessment}

Discrete grab samples were collected manually in amber-colored 11 glass recipients, three replicates by sample were taken from the middle of the stream and at mid-depth; they were labeled and refrigerated in a portable fridge. Sampling period was seven months. The variables analyzed were those in the National Sanitation Foundation index (NSF), pH, nitrates, phosphates, biological oxygen demand (BOD), dissolved oxygen, fecal coliform, total dissolved solids (TDS), turbidity and temperature. To calculate diversity and biological indexes for water quality was studied the composition of the EAM community. Samples were taken manually by using nets as indicated by Villamarín et al. (2013). Surface runoff was obtained using rainfall simulators (Otero et al. 2011). Physicochemical analyses of the water samples were developed according to the Standard Methods (APHA et al. 2012), the bacteriological and BOD tests were performed in a certified laboratory (15/12/05 Resolution No. 004645 of the Ministry of Social Protection).

\section{Anthropic and spatial analysis}

The human activities related to agricultural production were characterized by checklists. An influence-dependent matrix determined the main indicators related to water quality. These indicators were classified into four types: key, driver, regulatory, and resulting. The key variables are expressed directly in the dynamic of the system. The driver types are the variables that condition the system, generating synergies with other ones. The regulator types are those variables determining the change in the system according to its transformation by the effect of certain activities. Finally, those of the resulting type are representing the changes in the system.

The spatial locations of crops in the basin favor the sediment yield of nutrients and contaminants in runoff to the river. To analyze the distribution pattern of agricultural land use in the study area, a supervised classification of Landsat TM image (2010) was performed with a multi-spectral composition (bands $4,5,3)$ using the software ERDAS IMAGINE 9.1. A map of land use classification using Corine Landcover Colombia (level 3) was obtained and processed with the ArcMap Spatial Analysis module (Clusters). Using the software FRAGSTATS V.4 next variables were calculated: Total class area (CA), number of patches (NP), percentage of landscape (PLAND) and aggregation index $(\mathrm{Al})$ to quantify the grouping of crops in three subzones (upper, middle and lower) and its relation to the percentage of the occupied area.

\section{Experimental design}

Using a randomized design during seven months (June to December of 2013), a total of 630 samples were obtained to perform the physical and chemical analysis, integrating 10 variables and three replications in the study sites. The EAM sample plan included the exploration of different types of habitats such as mud, rocks, riparian and emerging vegetation, as well as rapids.

For the upper area, the climatic conditions were analyzed according to the daily rainfall data reported by Institute of Hydrology, Meteorology and Environmental Studies of Colombia (IDEAM); for the lower area, the climatic station of the University of Cauca-Environmental Study Research Group, provided the data.

The statistical analysis was performed by the software SPSS v.13.0, Statistica v.7.0, Past v.1.44, Estimates v.7.5 and Biodiversity Pro, which included a distribution analysis and data mining with A Kruskall Wallis and Mann Whitney U test gathering significant differences $(p<0.05)$ among variables, and a multivariate analysis to integrate the main parameters. 


\section{RESULTS}

\section{Physicochemical parameters}

The nitrate $\left(\mathrm{NO}_{3}^{-}\right) \mathrm{mg} / \mathrm{L}$ concentration oscillates from 0.60 to $3.47 \mathrm{mg} / \mathrm{L}$. The spatial and temporal variation was significant $(\mathrm{p}=0.01)$ and the minimum and maximum values across the basin were found during November and December. In this case, the rainfall has an influence on nitrate concentrations. The nitrates in surface runoff values range from 0.64 to $2.57 \mathrm{mg} / \mathrm{L}$ (Fig. 3). The nitrite $\left(\mathrm{NO}^{-}{ }_{2}\right)$ and ammonium $\left(\mathrm{NH}_{4}\right)$ concentration ranges between 0.01-1.12 $\mathrm{mg} / \mathrm{L}$ and $0.01-0.23 \mathrm{mg} / \mathrm{L}$ respectively, the $\mathrm{p}$ value (0.02-0.01).
The phosphates in the water vary from 0.09 to $4.29 \mathrm{mg} / \mathrm{L}$ and in surface runoff from 0.09 to $0.18 \mathrm{mg} / \mathrm{L}$, with significant temporal variation (Kruskall Wallis 0.02). Months with the lowest rainfall show differences in concentration (U test 0.03 ), which increases toward the lower area of the basin $(\leq 2000$ masl), where crops have a major extension (Fig. 3).

The $\mathrm{pH}$ values range from 6.59 to 7.80 units in the water, and between 6.1 and 6.71 units in the surface runoff. The spatial and temporal variations were a significant aspect to the rainfall, according to the Kruskall Wallis test $(\mathrm{p}<0.05)$. The lowest rainfall intensities were observed in the upper area with similar trend throughout the basin (Fig. 3).


Fig. 3. Spatiotemporal variation in water and runoff samples: (a) nitrates, (b) phosphates and (c) pH 
The water conditions were evaluated using the NSF index, pollution indexes as Suspended Solid Index (ICOSUS), contamination index by organic matter (ICOMO) and EAM community, which indicates an acceptable and poor rating for water quality. Results suggest that the contamination processes are caused by the excess of nitrogen and phosphorus (Hahn et al. 2012) in concordance with the percentage of crop fields in the upper, middle and lower zones of the basin (Fig. 4).

Plecoptera, Ephemeroptera, Trichoptera (PET) and Diptera organisms were found in the Las Piedras River. The total collection of EAM had a sample efficiency of $90 \%$. Organisms of the order Glossiphoniformes were found in upper areas of the basin, Hemiptera organisms in the middle area, and Nematomorpha in the lower area. Variations of abundance and richness were not significant $(\mathrm{p}=0.01$ Kruskall Wallis). The middle area had the highest diversity while the upper area showed the most abundance of species.

The similarity of the EAM communities across sampling sites was assessed using cluster analysis. The results indicate that samples collected in the lower area were the most dissimilar, and a relationship exists between the sites in the upper and middle areas (Fig. 5).

Biological indexes (Table I) showed that diversity is medium in the upper and middle areas, with high dominance and low equitability, while the lower area was the least diverse. Water quality was also evaluated considering the presence of EAM families and their tolerance to pollution by calculating the BMWP quality index (Fig. 6).
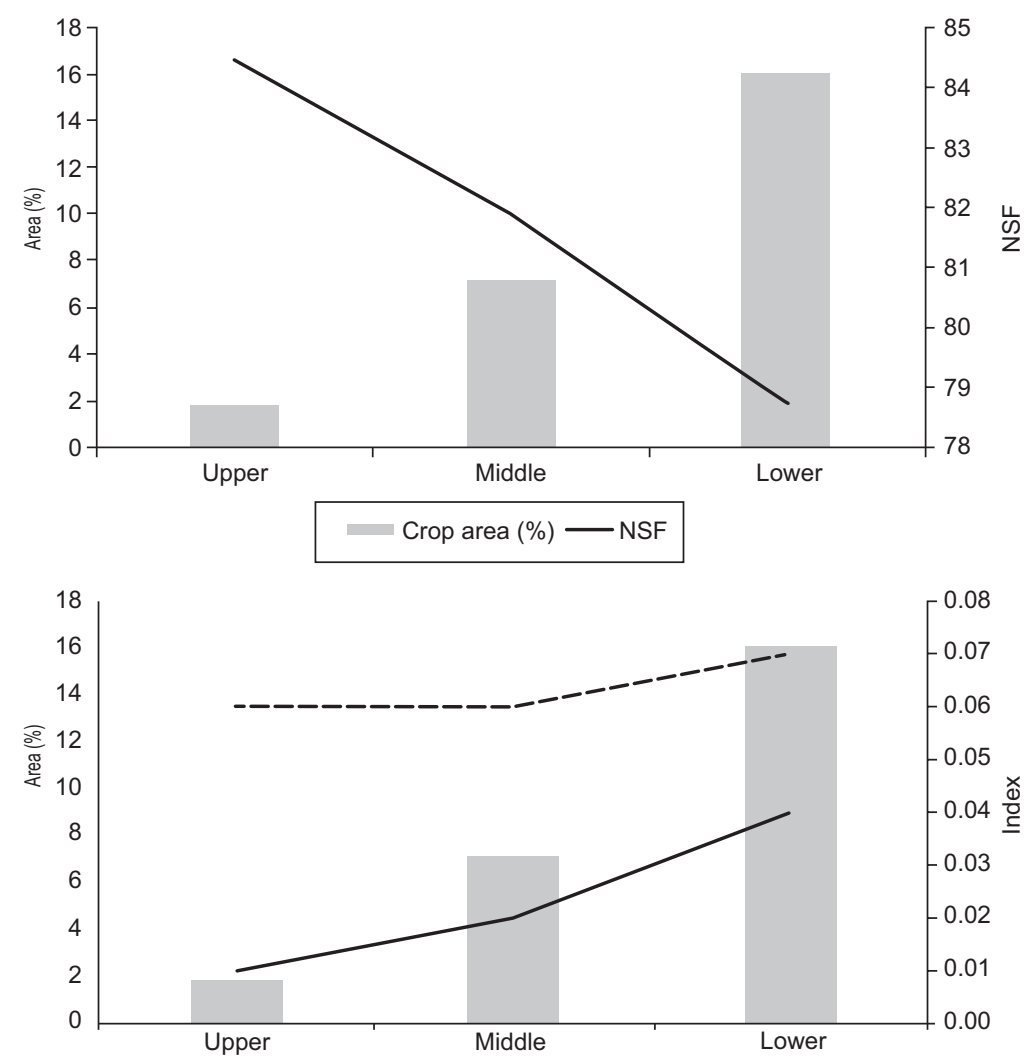

Crop area $(\%)$

— Organic pollution index ICOMO

- - Suspended solids index ICOSUS

Fig. 4. Crop field area by zones and pollution indexes. NSF $=$ National Science Foundation index, icomo $=$ organic pollution index, icosus $=$ suspended solids index 


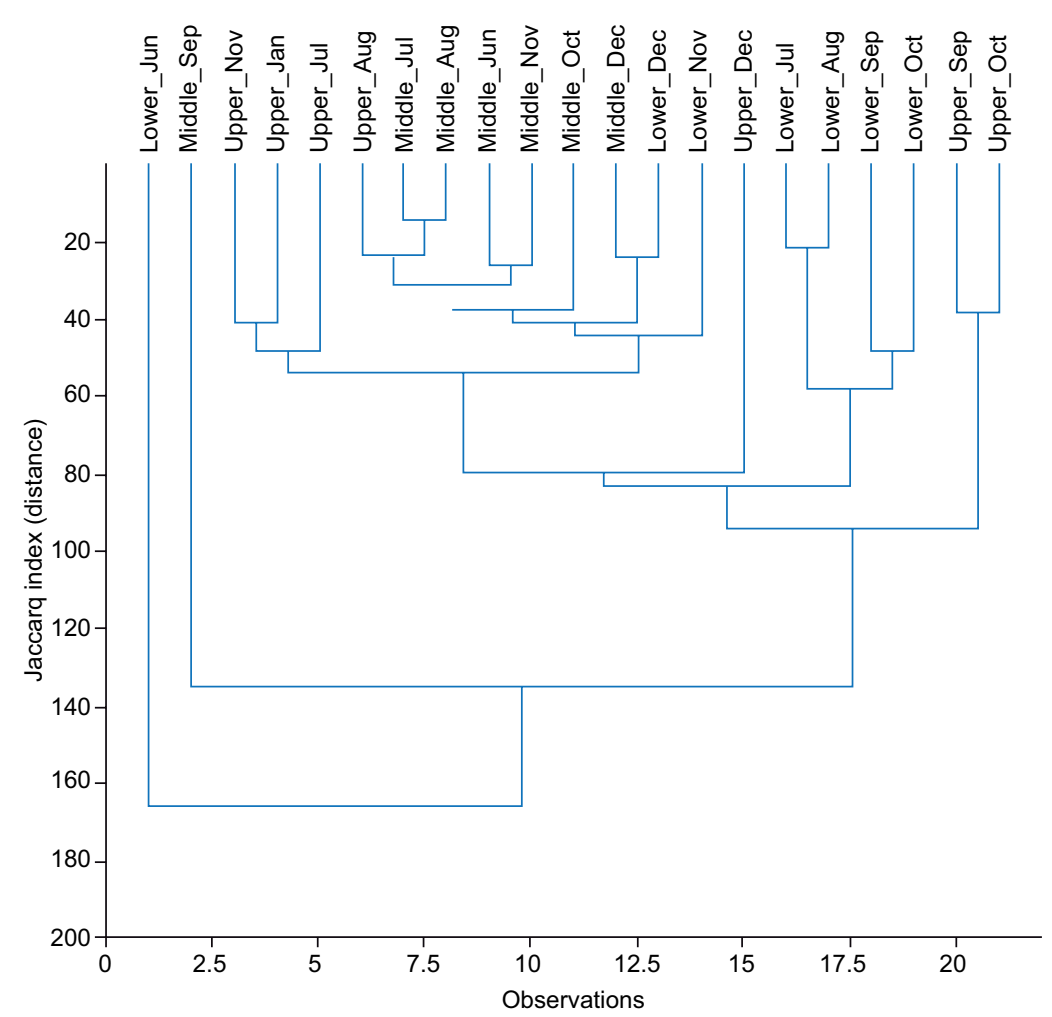

Fig. 5. Cluster of similarity between sites and sampling months in the study area

TABLE I. BIOLOGICAL INDEXES IN LAS PIEDRAS RIVER

\begin{tabular}{llrrrrrrr}
\hline Site & Index & Jun & Jul & Aug & Sept & Oct & Nov & Dec \\
\hline Upper & BMWP & \multicolumn{1}{c}{85} & \multicolumn{1}{c}{122} & 102 & 156 & 142 & 148 & 135 \\
& Shannon H & 2.26 & \multicolumn{1}{c}{2.6} & 2.52 & 2.47 & 2.21 & 2.36 & 2.2 \\
& NSF & 88.22 & 79.64 & 83.18 & 85.29 & 79.63 & 86.70 & 88.40 \\
& ICOMO & 0.02 & 0.00 & 0.02 & 0.00 & 0.00 & 0.04 & 0.00 \\
& ICOSUS & 0.06 & 0.07 & 0.08 & 0.05 & 0.07 & 0.06 & 0.05 \\
& Phosphates & 0.60 & 0.13 & 1.47 & 1.18 & 0.13 & 0.20 & 0.18 \\
& Nitrates & 1.20 & 1.53 & 1.27 & 1.10 & 1.60 & 0.67 & 1.03 \\
\hline Middle & BMWP & 95 & 112 & 130 & 158 & 113 & 114 & 131 \\
& Shannon H & 2.49 & 2.29 & 2.48 & 2.28 & 2.51 & 2.43 & 2.49 \\
& NSF & 82.46 & 82.34 & 81.98 & 81.74 & 80.65 & 82.02 & 81.93 \\
& ICOMO & 0.03 & 0.02 & 0.01 & 0.01 & 0.04 & 0.02 & 0.02 \\
& ICOSUS & 0.05 & 0.06 & 0.05 & 0.06 & 0.07 & 0.06 & 0.06 \\
& Phosphates & 0.48 & 0.29 & 1.45 & 1.03 & 0.48 & 0.63 & 0.11 \\
& Nitrates & 1.70 & 1.80 & 1.60 & 1.40 & 1.40 & 0.83 & 1.33 \\
\hline Lower & BMWP & 89 & 110 & 102 & 112 & 108 & 124 & 92 \\
& Shannon H & 1.11 & 1.77 & 1.8 & 2.13 & 2.19 & 2.53 & 2.25 \\
& NSF & 80.78 & 81.27 & 84.92 & 81.74 & 74.69 & 73.98 & 74.00 \\
& ICOMO & 0.08 & 0.00 & 0.02 & 0.00 & 0.06 & 0.07 & 0.06 \\
& ICOSUS & 0.06 & 0.08 & 0.09 & 0.06 & 0.06 & 0.06 & 0.05 \\
& Phosphates & 0.45 & 0.35 & 1.49 & 1.36 & 0.12 & 0.69 & 0.30 \\
& Nitrates & 1.80 & 1.80 & 2.20 & 1.87 & 1.80 & 1.00 & 1.87 \\
\hline
\end{tabular}

* The highlighted values indicate some alteration processes. BMWP = biological monitoring working party index, NSF = National Science Foundation index, ICOMO = organic pollution index, ICOSUS $=$ suspended solids index 


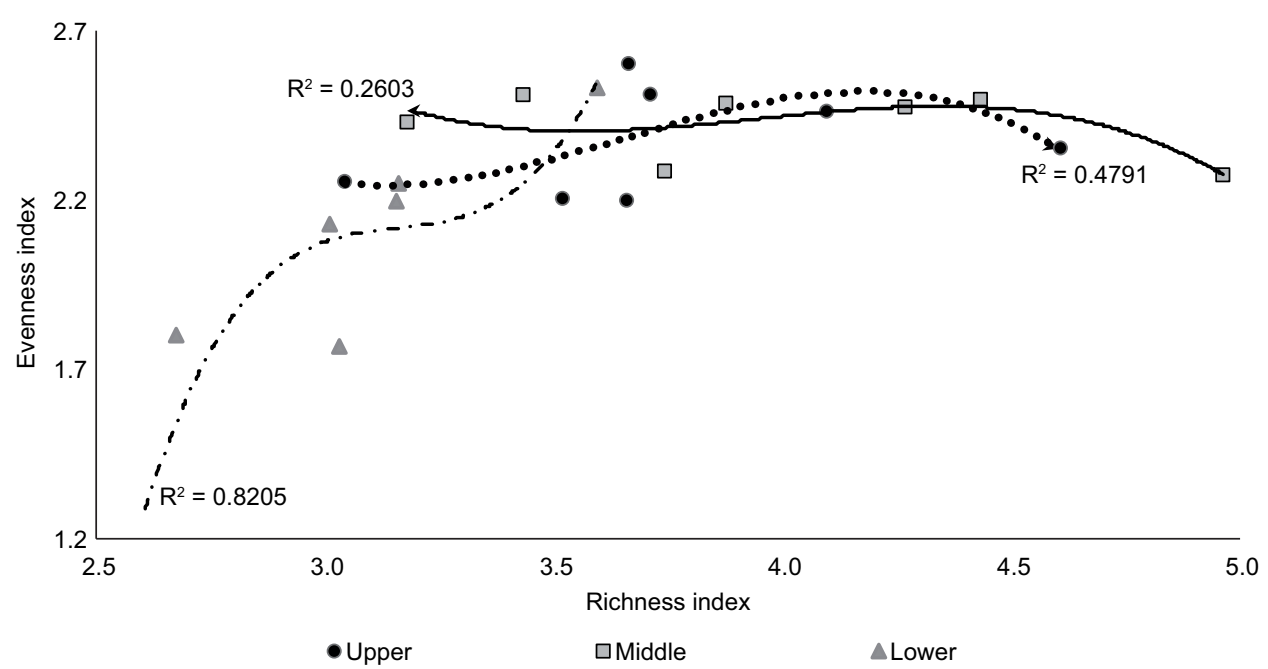

Fig. 6. Coefficient of determination $\left(\mathrm{R}^{2}\right)$ for diversity indexes. Evenness (Shannon $\mathrm{H}^{\prime}$ index) and richness (Margalef index).

The next figure shows the correlation by the sample site between the specific richness and the evenness diversity, the $\mathrm{R}^{2}$ indicated the high values for the lower zone (0.82).

\section{Human activities impact}

According to the evaluation matrix, anthropogenic activities were observed: riparian area transformation (V1), replacement of native vegetation by production areas (V2), landscape fragmentation (V3), agriculture techniques (V4), crop field's expansion (V5), fertilizer use (V6), community organization and participation (V7), livestock (V8), vehicular traffic (V9), crop production (V10), forest conservation (V11), local climate variability (V12), runoff, soil erosion and nutrient loss (V13), changes in the physicochemical water quality (V14), and modification of the EAM community (V15).

The distribution of the driver (I), key (II), regulatory (III) and resulting (IV) variables in the direct influence/dependency plane (Fig. 7) and the map (Fig. 8) represents the variables that exert direct influences in the basin transformation and ecological condition. In this sense, the agricultural techniques determine the crop production and the fertilizer use which cause changes in the physicochemical water quality and modification of the EAM community. The social organization and the agricultural techniques affect the forest conservation and this with the replacement of native vegetation to production areas, influence the local climate variability and the runoff, soil erosion and nutrient loss (Ruiz et al. 2015).

The natural land-cover in the basin ranges during the period 1989-2010 showed a reduction of 49 ha

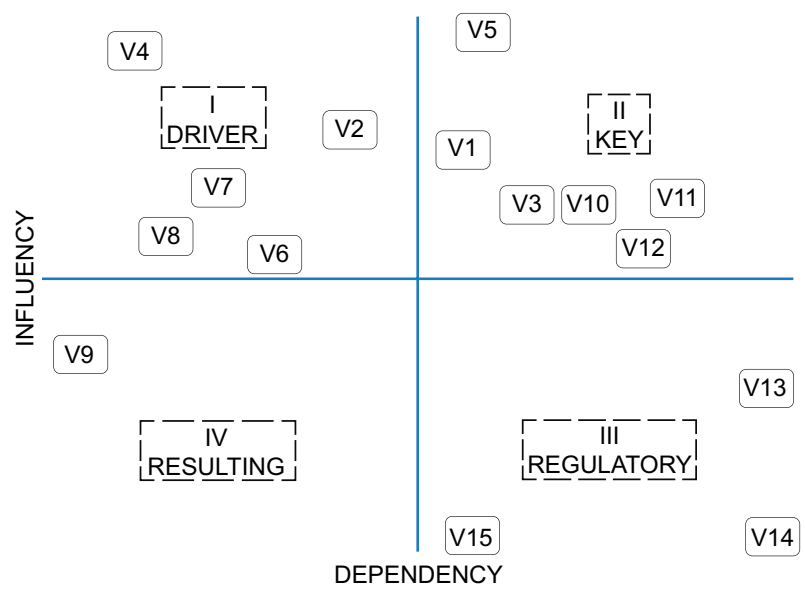

Fig. 7. Influences and dependencies

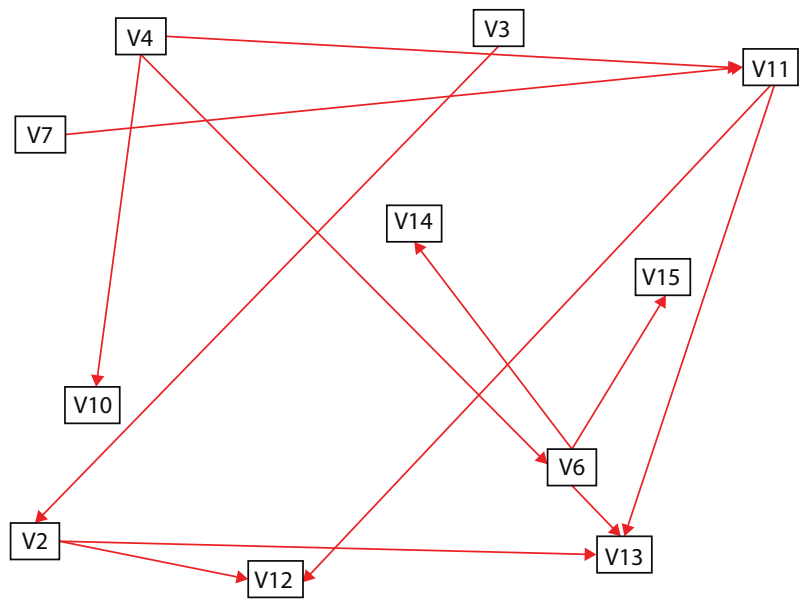

Fig. 8. Map of direct influences 
in the Paramo, and $\sim 850$ ha in succession zones (shrublands and riparian vegetation). As a result of agricultural activities expansion, crop fields increased by $9.4 \%$ in the same period. Crop fields are spatially aggregated and their extension increases towards the lowest area of the basin. In the upper area, field crops occupy $1.9 \%, 7.2 \%$ in the middle area and in the lower basin extend to $16.1 \%$. Those situations modify the ecological relationships between the components in the river. This can be seen by relating the value of the NSF water quality index, and the nutrient concentration $\left(\mathrm{PO}_{4}\right)$ with the percentage of crops, which has a positive relationship (Fig. 9).

The forest fragmentation and the crop field's expansion increase the erosive processes, concomitant losses of organic matter, nutrients and other key elements involved in soil's fertility. Soil is also affected by land preparation for agriculture; tillage tools or machinery turns it and this modifies the function of the soil pore matrix, thus, changing the structural stability (Otero et al. 2011).

Additionally, the management activities are limited by the land tenure conflicts, this situation becomes more complex in extreme climatic events such as ENSO (E1 Niño Southern Oscillation), which has generated the construction of open channels along the basin to carry out water for domestic, agricultural and fishery uses, affecting the ES in the watershed (Valencia et al. 2014).

\section{Multivariate statistical analysis}

Negative correlations with the spatial variation were identified between the phosphates in the surface runoff and quality-diversity indexes (physical and chemical NSF and Shannon $\left(\mathrm{H}^{\prime}\right)$ and Margalef biological diversity indexes). Also the nutrient input varies with the elevation in the basin. In the lower area there was an increase of the phosphates concentration, the dominance of some EAM species and the pollution according to the NSF index (Fig. 10). The climatic condition was negatively correlated with $\mathrm{pH}$ and phosphates variables along the basin.

Positive correlations were found between the nitrates in the surface runoff with the $\mathrm{pH}$ since the nutrient becomes soluble in acid conditions such as in the Andean soils. Additionally the correlation
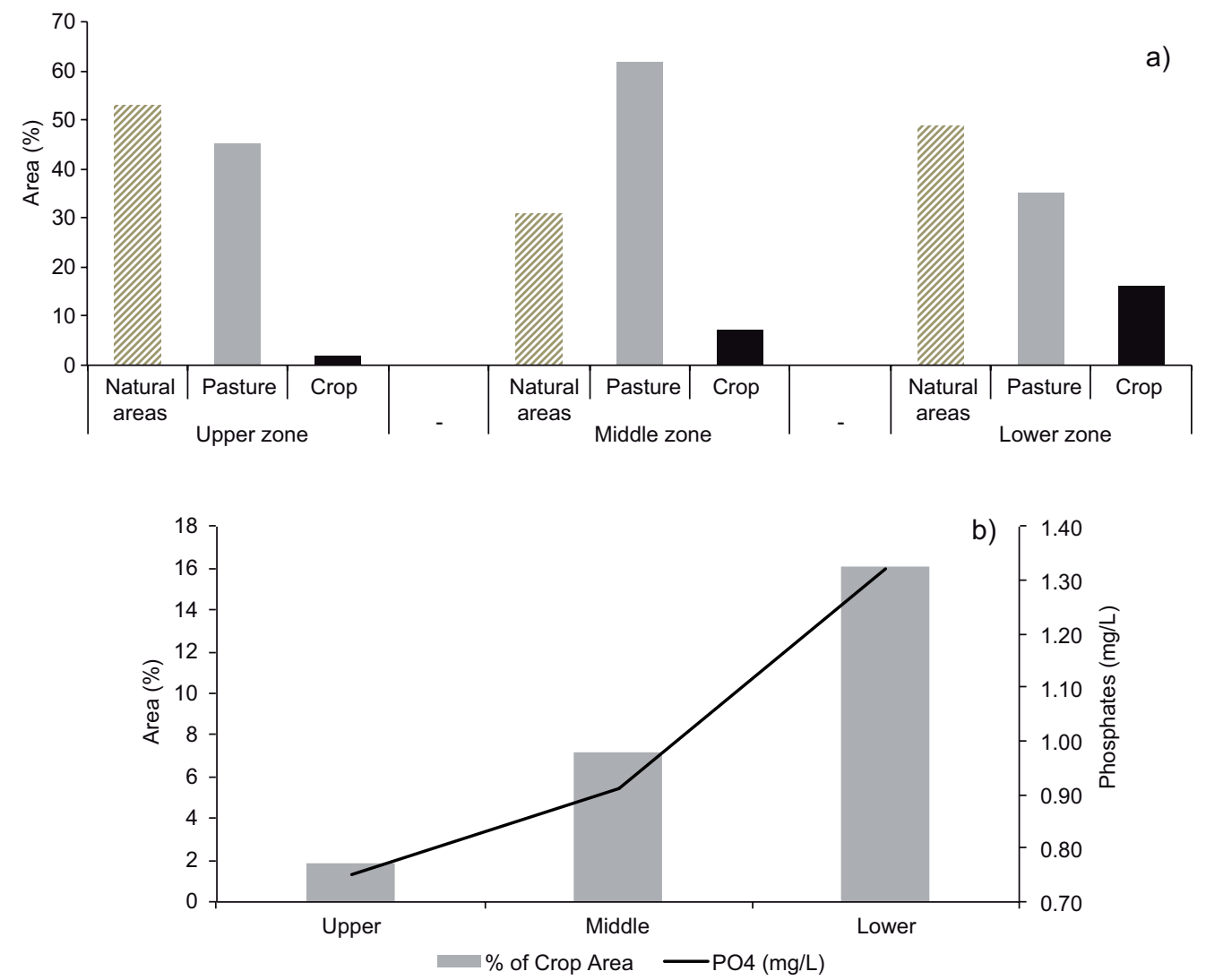

Fig. 9. Percentage of landcover areas by zones (a) and nutrient concentration $\left(\mathrm{PO}_{4}\right)$ related to \% crop area by zones (b) 


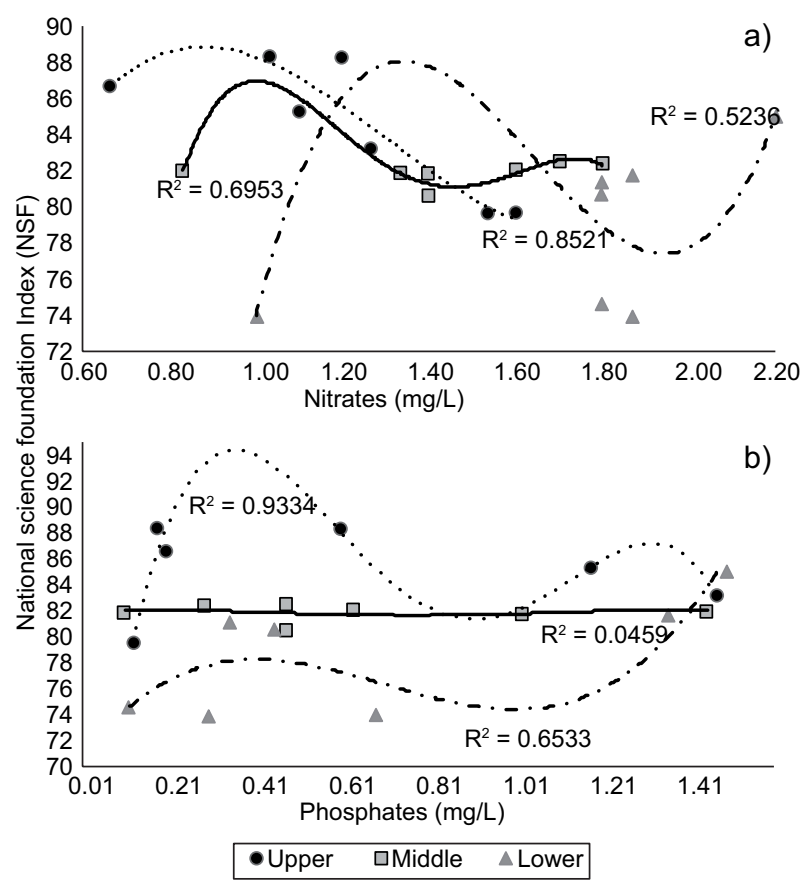

Fig. 10. Nutrients variation in contrast to the National Science Foundation index (NSF): a) nitrates variation, b) phosphates variation. $\mathrm{R}^{2}=$ coefficient of determination

between phosphates in the surface runoff with the diversity-quality indexes, results from the agricultural activities near the river as it can be seen in the crop spatial distribution map (Fig. 2), with major density in the lower zone of the basin.

According to the multivariate tests (Fig. 11) there were differences between the sample sites, in the upper zone the biological indexes were high, the middle zone was influenced by surface runoff parameters ( $\mathrm{pH}$ and nitrates) and the phosphates in the stream, finally in the lower area the correlated variables were an abundance of EAM and nitrates in the river.

Peasants determine the land use and management depending on the climatic variation, at the same time this management drives the movement of phosphates from soil to water affecting the $\mathrm{pH}$ and the water quality as is demonstrated by the biological index. The $\mathrm{pH}$ in surface runoff (acid) was directly correlated with the water $\mathrm{pH}$ (basic) and negatively related with the biodiversity (factor 2).

\section{DISCUSSION}

\section{Water quality analysis}

The physicochemical variations were within the optimum limits for the development of EAM communities favored by the high depuration capacity of the river as the oxygen saturation indicates $(\leq 80 \%)$. When the temperature is low $\left(12.30^{\circ} \mathrm{C}\right)$, the oxygen level rises $(8.23 \mathrm{mg} / \mathrm{L})$, this occurs in the months of highest precipitation (October and November $>120 \mathrm{~mm}$ ). During the periods of low rainfall (August and September $>28 \mathrm{~mm})$, the temperature increases $\left(\Delta 5^{\circ} \mathrm{C}\right)$ while oxygen decreases $(>7 \mathrm{mg} / \mathrm{L})$ showing an inverse correlation between them.

The lowest values of $\mathrm{pH}(6.59 \mathrm{pH}$ units $)$ in the upper area during the periods of high rainfall were caused by the increase of suspended particles and organic matter, which contributes to surface runoff from fields with unprotected bare soil exposed to the direct impact of raindrops. In this condition the soil will be easily transported by surface laminar flow favored by the topography in the basin, which has long $(>30 \mathrm{~m}$ ) and steep terrain slopes (up to $50 \%$ ).

This is a milestone for the basin management because if the rate of surface runoff is high this can go from a transportation detachment factor to a more serious problem by increasing pollution in rivers and aquatic ecosystems. The average $\mathrm{pH}$ (7.2) in the stream indicates a neutral condition, but the variations in the upper area evidence a threat in supporting ecological processes such as photosynthesis, respiration, decomposition and biodiversity (Shannon $\mathrm{H}^{\prime}$ 2.6) which are related to climatic variation and fertilizer uses in crops.

The turbidity concentration varies according to the altitude of the basin, it was the lowest in the upper area 1.30 nephelometric turbidity units (NTU) and then increased slightly toward the lower area 1.90 to $4.70 \mathrm{NTU}$. This is related to crop localization and the reduction of riparian vegetation favoring the erosion; according to a study in the river this fringe is composed by 55 species, 43 genus, 31 families and the Margalef index denotes medium biodiversity (3.3) (Recaman 2006).

An atypical value for turbidity (5.90 NTU) was found in the lower area during October, the high rainfall month $(44.18 \mathrm{~mm} / \mathrm{h})$, resulting by the increased dragging of sediments, erosion and solid transportation. Overall, reported values of turbidity were low (1.30 to 5.90 NTU), which do not affect the development of aquatic biota. Physical variables of conductivity and turbidity are within the standard values for human consumption, agricultural and livestock activities.

The nutrient analysis in the basin revealed a relationship with agriculture, as demonstrated by phosphate concentrations exceeding $1 \mathrm{mg} / \mathrm{L}$ (Henle et al. 2008, Hahn et al. 2012), considered as pollution indicator (Van Oudenhoven et al. 2012). The 


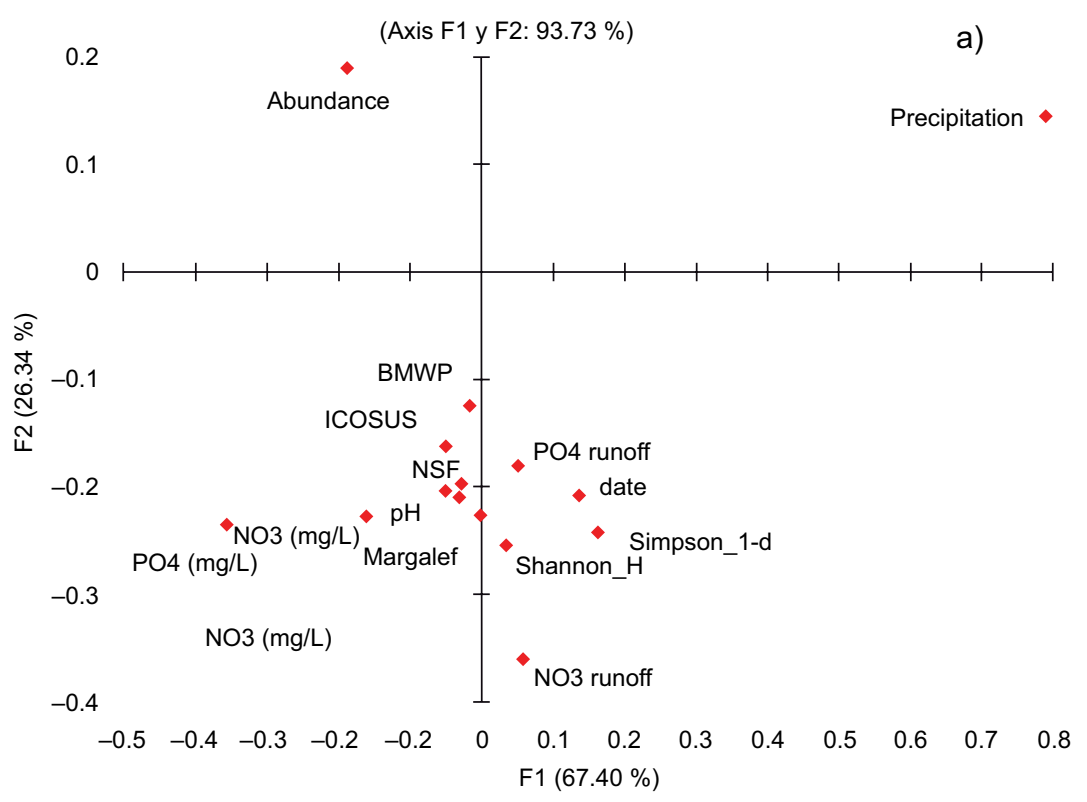

b)
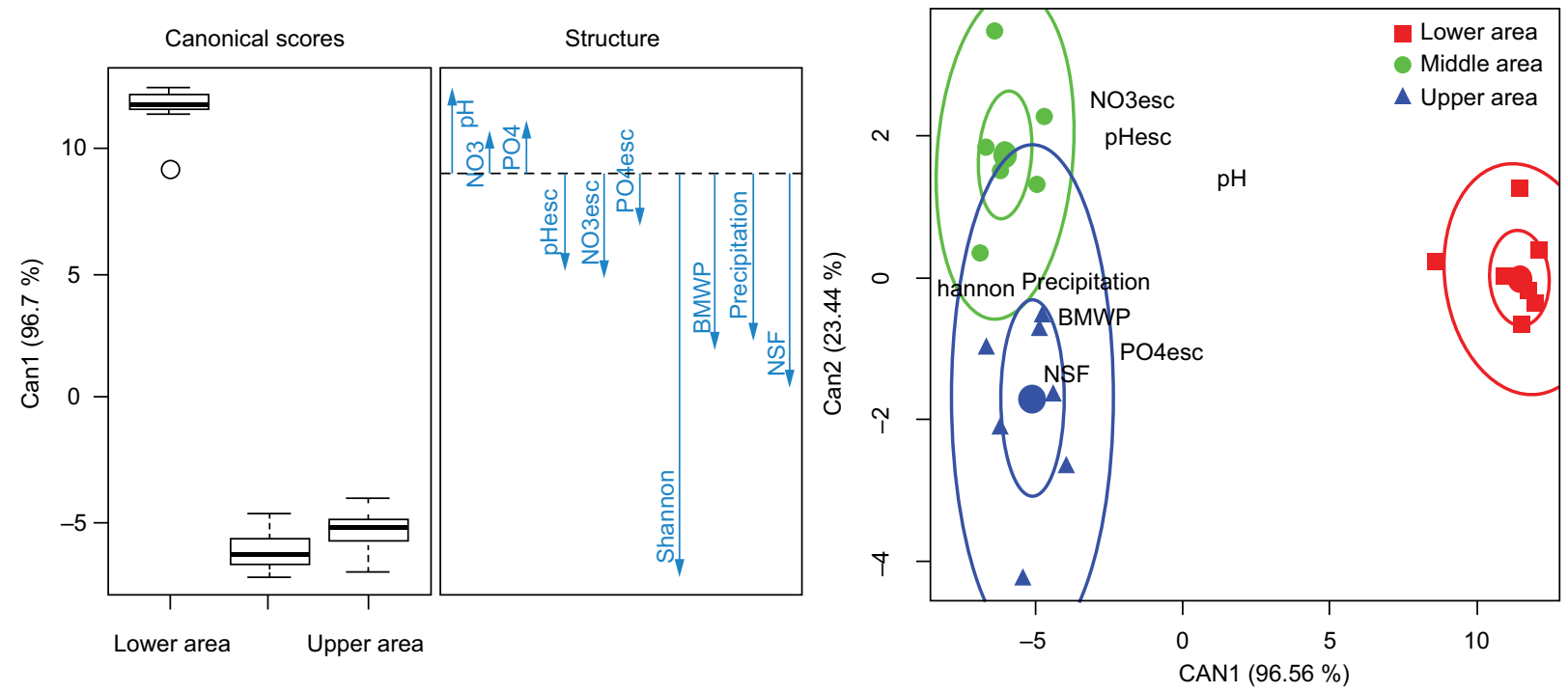

Fig. 11. Statistical multivariate analysis: a) factorial analysis, b) linear discriminant analysis (LDA)

input of the nutrients comes mainly from agricultural activities and livestock management as observed in the fields adjacent to the sampling sites. Nitrates and phosphate concentrations were high during months with lower rainfall when the river reduces its dissolution capacity.

The basin had high concentrations of oxygen (6.91 to $8.33 \mathrm{mg} / \mathrm{L})$, low temperatures $\left(12{ }^{\circ} \mathrm{C}\right.$ to $17.70^{\circ} \mathrm{C}$ ), and a neutral $\mathrm{pH}$, there nitrogen could be found in its oxidized state. The presence of nitrites $(<0.1 \mathrm{mg} / \mathrm{L})$ is related to water pollution (Liu et al.
2014) caused by the drag of agricultural inputs and livestock (manure), accentuated in periods of low rainfall (Miserendino et al. 2011).

The nitrate variation was higher than nitrite $\left(\mathrm{NO}_{2}^{-}\right)$and ammonium $\left(\mathrm{NH}_{4}\right)$, denoting high availability of nutrients for primary producers but without eutrophication (Mouri et al. 2011). The temporality influenced the nitrate concentrations during rainy season; the nitrites were highly soluble in acid andean soils ( $\mathrm{pH}$ ranges from 6.1 to 6.7), which facilitates its transportation by surface runoff to the mainstream. 
The Andisols porosity retains water during drought periods and the phosphates attaches to iron and aluminum (Otero et al. 2011). Moreover there was a positive correlation between physicochemical parameters (conductivity, nitrates) and sample sites due to the increase concentration toward the lower area.

Although nitrite concentrations were low $(<0.1 \mathrm{mg} / \mathrm{L})$, these were higher in the lower areas of the basin, due to intensification of agriculture that provides the excessive organic matter during rainfall events. Similarly the nutrient input into water streams was the effect of runoff from crops with the liberation of stable organometallic complexes from Andisols, which was left, exposed by the agricultural techniques (Chang 2008, Mouri et al. 2011).

The salinity $(>50 \mu \mathrm{S} / \mathrm{cm})$ indicated mesotrophic conditions not expected in high mountain basins. However, a degradation process was noted in water quality in the lower areas by the increase of conductivity, according to TDS and ions concentrations (nitrate, nitrite and phosphate). In extension, anthropogenic pressures in the lower area caused fluctuations in the ionic activity, mainly by agricultural activity (Mouri et al. 2011). It was especially evident during the periods of low and medium rainfall.

The physicochemical parameters outlined above were related to the biological conditions in the river (Lock et al. 2011, Molozzi et al. 2012). Diversity of habitats and food supply favor the emergence of stenotypes' species such as Atopsyche, Tricorythodes, Elmoparnus, Chimarra, Corydalus, Limnocoris. The presence of euritipyc organisms like Thraulodes, Anchytarsus, Hidropsyche, Helicopsyche and Rhagovelia in the sample sites, indicates alteration in the biological quality caused by the availability of organic matter, which increases the presence of Chironomidae, Muscidae and Tipulidae families.

The analysis of $\beta$ diversity by Jaccard coefficient showed an isolated sample site in the lower basin area with EAM of the orders Diptera (tipulidae), related with pollution conditions (Lock et al. 2011, Molozzi et al. 2012). In contrast, other sampling sites had a relationship up to $50 \%$ with dominant orders such as Coleoptera, Ephemeroptera and Trichoptera.

The results of Alfa diversity for the benthic community showed an alteration process in water quality, with proliferation of some pollution tolerant taxonomic groups (Simulium, Tipula). During the high rainfall months the Trichoptera order was dominant; represented by the Hidropsychidae, Leptophlebiidae and Chironomidae families, and its genders Smicridea Thraulodes, and Chironomus respectively, which are indicators of oligomesotrophic water (Lock et al. 2011, Villamarín et al. 2013).

The lower area of the basin had the lowest diversity and evenness (Shannon 1.1) with high dominance of species (B. Parker 0.7) especially of the Diptera order ( $>10 \%$ of all collected organisms) with predominance of detritivores of the Muscidae family and the collectors of the Chironominae family and Simulium gender (Cummins Merrit and Andrade 2005). Based on the response to organic pollution (saprophytic approach), the lower area is characterized by high concentrations of organic matter, which is favored by agriculture activity and pasture fields located in the middle area.

In general, the water quality in the Las Piedras River was good. However, there was an increase in the concentrations of ammonia, nitrite and $\mathrm{pH}$ in November, and consequently the alteration of the water quality index NSF (73.98). Another important variable was the bacteriological pollution with presence of fecal coliforms in the whole basin. This was a relevant finding considering that the water is mainly use for human consumption and agriculture by local population.

\section{Human activities and water quality}

The results of physicochemical and biological analysis evidenced the influence of agriculture activities on water quality in the stream. Thus pasture management for continues livestock in the basin has generated soil compaction, changes in the physical, chemical and biological processes affecting the runoff and the consequent loss of structural stability which increases vulnerability to erosion and mass removals (Buytaert et al. 2006). For Andean pasture soils erosion has been estimated by $0.04 \mathrm{t} / \mathrm{ha} /$ month (Otero et al. 2011). Additionally, free access of cattle to the streams was observed with inputs of bacterial pollution from excreta, which affects the water for human consumption (García and Brown 2009, Rojas et al. 2011).

The agricultural production areas in the basin became more extensive but forest and vulnerable ecosystems are at a loss (Martínez and Figueroa 2009). Consequently the use of agrochemicals intensifies the erosion and pollution by the changes in the $\mathrm{pH}$ and the carried by runoff of nitrates and phosphates which increases the concentrations of nutrients in the streams; a study reported lost soils in Andean basins with agricultural uses of $0.39 \mathrm{t} / \mathrm{ha} / \mathrm{month}$ on average (Jordán and Martínez 2008). In order to keep erosion under reasonable (i.e., soil loss rates below $0.18 \mathrm{t} / \mathrm{ha}$ ) limits in the basin it is necessary to 
reduce the terrain slope gradient below $40 \%$, increase plant cover above $35-40 \%$, and evaluate erosion hotspots through models and multi scale (Baigorria and Romero 2007).

The dragging of nutrients by surface runoff had an increase during the rainy months of November and December. The high precipitation, the bare soils and the crop techniques on steep slopes with the crop arrangement up to $15 \mathrm{~m}$ in length favored the erosion in this Andean basin (Otero et al. 2011, Mosquera et al. 2014). Also forest fragmentation generated more vulnerability to erosion and affected the hydrologic cycle regulation as is widely explained in researches, the soil exploitation increased the concentration of pollutants in water sources, limits the water supply and alters the biodiversity in the basin (Boelens 2012, Ouyang et al. 2014).

With respectw to water quality and the Integrated Resources Water management (IWRM) policies, the Colombian regulation states protective forest reserve areas for the conservation and preservation of water (law 79 of 1986, in the Article 1). Similarly, IWRM strategy in the Andean basins extends these areas to all existing forests and natural vegetation in a strip not less than one hundred meters wide each side of the beds of the rivers, creeks and streams. The law's purpose was to maintain the retention and filtering runoff processes while avoiding the input of sediments to the mainstream. However, the spatial analysis in this research demonstrated the problems with the riparian strip due to the not correspondence with the established legislation.

In the socio political context the local institutions have taken special care in the use and management of these water resources. They have engaged local farmers and indigenous communities in environmental education processes (PNUD 2010, Figueroa et al. 2012). Therefore the influence of some agriculture practices currently performed in the basin should be considered since the evidence of high nutrient concentrations and pathogenic organisms limits resource availability for human consumption, benthic communities and aquatic ecosystem trophic dynamics to long term.

\section{CONCLUSIONS}

The transformation of this Andean basin results from productive activities, mainly to attend the needs for food, shelter, and economic income of the social groups that inhabit the territory. But this process of land occupation and appropriation of the natural resources and ES had been addressed to primary production. Therefore, agriculture is the main driver of pollution and degradation of water resources, affecting future water supply availability. Specifically planting techniques, use of chemical inputs, water supply, and crop irrigation are modifying the physicochemical and biological characteristics of the river.

The variations in the concentration of nitrates, phosphates and the fecal coliforms bacteria are related to pollution, limiting human water consumption and biodiversity. In this case, the presence of Ephemeroptera, Plecoptera and Trichoptera orders shows good biological water quality conditions in general; but the nutrient inputs, as a result of inadequate agricultural activities, allow the coexistence in some sites of pollution-tolerant organisms with species of the Simulium, Tipula, Dytiscus and Physa genders, which threatens the water availability for domestic usages.

The discriminant analysis shows that the lower zone is characterized by the high concentration of nitrates, phosphates and $\mathrm{pH}$ while rates are low diversity and quality ( $96.7 \%$ of variance), in this sense the critical areas showed increased nutrient concentrations toward the middle and lower part of the river where the crop aggregation is greater.

The pollution processes are accentuated in the lower basin area especially by agriculture, livestock, and fisheries, limiting the ES of water supply for human consumption. The presence of coliform and nutrient concentrations also limits the supply for domestic use, a situation that is considered by the water supply industry for water management purposes.

\section{ACKNOWLEDGMENTS}

This research was performed with the support of the Department of Science Technology and Innovation Colciencias in Colombia, through the bicentennial scholarship program "Young research and doctoral students". Thanks to the foundation río Las Piedras and the environmental study group in the University of Cauca.

\section{REFERENCES}

Andrade A. and Stigter T. (2009). Multi-method assessment of nitrate and pesticide contamination in shallow alluvial groundwater as a function of hydrogeological setting and land use. Agr. Water. Manage. 96 (12), 1751-1765. DOI: 10.1016/j.agwat.2009.07.014 
APHA (2012). Standard methods for the examination of water and wastewater. 22a ed. American Public Health Association. Washington, USA, $1350 \mathrm{pp}$.

Baigorria G. A. and Romero C. C. (2007). Assessment of erosion hotspots in a watershed: integrating the WEPP model and GIS in a case study in the Peruvian Andes. Environ modell. Softw. 22 (8), 1175-1183. DOI: 10.1016/j.envsoft.2006.06.012

Balthazar V., Vanacker V., Molina A. and Lambin E. F. (2015). Impacts of forest cover change on ecosystem services in high Andean mountains. Ecol. Indic. 48, 63-75. DOI: 10.1016/j.ecolind.2014.07.043

Balvanera P., Uriarte M., Almeida-Leñero L., Altesor A., DeClerck F., Gardner T. and Vallejos M. (2012). Ecosystem services research in Latin America: The state of the art. Ecosyst. Serv. 2, 56-70.

DOI: 10.1016/j.ecoser.2012.09.006

Bates B.C., Kundzewicz Z.W., Wu S. and Palutikof J.P. (2008). El cambio climático y el agua. 1a ed. Panel Intergubernamental de Expertos sobre el Cambio Climático. Geneva, Switzerland, 224 pp.

Boelens R. and Vos J. (2012). The danger of naturalizing water policy concepts: Water productivity and efficiency discourses from field irrigation to virtual water trade. Agr. Water. Manage. 108, 16-26.

DOI: $10.1016 /$ j.agwat.2011.06.013

Buytaert W., Célleri R., De Bièvre B., Cisneros F., Wyseure G., Deckers J. and Hofstede R. (2006). Human impact on the hydrology of the Andean páramos. Earth-Sci. Rev. 79 (1-2), 53-72.

DOI: $10.1016 /$ j.earscirev.2006.06.002

Chang H. (2008). Spatial analysis of water quality trends in the Han River basin, South Korea. Water Res. 42 (13), 3285-3304. DOI: 10.1016/j.watres.2008.04.006

Chung N., Bae M.J., Li F., Kwon Y.S., Kwon T.S., Kim J.S. and Park Y.S. (2012). Habitat characteristics and trophic structure of benthic macroinvertebrates in a forested headwater stream. J. Asia Pac. Entomol. 15 (3), 495-505.

DOI: $10.1016 /$ j.aspen.2012.05.002

Cobo Q. (1998). Diseño, construcción y evaluación de un mini simulador portátil de lluvia para estudios de susceptibilidad a erosión en laderas. BSc Thesis. Facultad de Ingeniería. Universidad del Valle. Santiago de Cali, Colombia, 120 pp.

Cummins K. W., Merrit R.W. and Andrade P. C (2005). The use of invertebrate functional groups to characterize ecosystem attributes in selected streams and rivers in southeast Brazil. Stud. Neotrop. Fauna E. 40 (1), 6989. DOI: $10.1080 / 01650520400025720$

Figueroa A., Martínez J. P., Valencia M. and Joaqui S. (2012). Programa monitoreo ambiental para cambio climático en ecosistemas agricolas altoandinos. In:
Ciencia y tecnología para la competitividad del sectro agropecuario 2002-2010. (J. Tobón, N. Velásquez, Eds.). Agropress, Bogotá, Colombia, 180-190 pp.

Frank S., Fürst C., Koschke L. and Makeschin F. (2012). A contribution towards a transfer of the ecosystem service concept to landscape planning using landscape metrics. Ecol. Indic. 21, 30-38.

DOI: 10.1016/j.ecolind.2011.04.027

García C. R. and Brown S. (2009). Assessing water use and quality through youth participatory research in a rural Andean watershed. J. Environ. Manage. 90 (10), 3040-3047. DOI: 10.1016/j.jenvman.2009.04.014

Guo W., Fu Y., Ruan B., Ge H. and Zhao N. (2014). Agricultural non-point source pollution in the Yongding River Basin. Ecol. Indic. 36, 254-261.

DOI: $10.1016 /$ j.ecolind.2013.07.012

Hahn C., Prasuhn V., Stamm C. and Schulin R. (2012). Phosphorus losses in runoff from manured grassland of different soil P status at two rainfall intensities. Agric. Ecosyst. Environ. 153, 65-74. DOI: 10.1016/j.agee.2012.03.009

Henle K., Alard D., Clitherow J., Cobb P., Firbank L., Kull T. and Rebane M. (2008). Identifying and managing the conflicts between agriculture and biodiversity conservation in Europe-A review. Agric. Ecosyst. Environ. 124 (1-2), 60-71. DOI: 10.1016/j.agee.2007.09.005

IDEAM (2007). Protocolo para el monitoreo y seguimiento del agua. $2 \mathrm{a}$ ed. Instituto de Hidrología, Meteorología y Estudios Ambientales. Bogotá, Colombia, 92 pp.

IWMI (2007). Comprehensive assessment of water management in agriculture. 1a ed. International Water Management Institute. London, UK, 176 pp.

Jordán A. and Martínez-Zavala L. (2008). Soil loss and runoff rates on unpaved forest roads in southern Spain after simulated rainfall. For. Ecol. Manage. 255 (3-4), 913-919. DOI: 10.1016/j.foreco.2007.10.002

Liu R., Wang J., Shi J., Chen Y., Sun C., Zhang P. and Shen Z. (2014). Runoff characteristics and nutrient loss mechanism from plain farmland under simulated rainfall conditions. Sci. Total Environ. 468-469, 10691077. DOI: $10.1016 /$ j.scitotenv.2013.09.035

Llausàs A. and Nogué J. (2012). Indicators of landscape fragmentation: The case for combining ecological indices and the perceptive approach. Ecol. Indic. 15 (1), 85-91. DOI: 10.1016/j.ecolind.2011.08.016

Lock K., Asenova M., Parker L., Achard G., Hugh F., Stibig H.J. and Malingreau J.P. (2011). Benthic macroinvertebrates as indicators of the water quality in Bulgaria: A case-study in the Iskar river basin. Limnologica 41 (4), 334-338. DOI: 10.1016/j.limno.2011.03.002

Martínez J. P. and Figueroa A. (2009). Cambios de cobertura y fragmentación a través de un análisis espacio temporal en el parque nacional natural Puracé. 
In: Fragmentación y coberturas vegetales en ecosistemas andinos, Departamento del Cauca. (A. Figueroa and M. Valencia, Eds.). Universidad Del Cauca, Popayán, Colombia, pp. 137-155.

MAVDT (2010). Política Nacional para la Gestión del Recurso Hídrico. 1a ed. Ministerio de Ambiente Vivienda y Desarrollo Territorial. Bogotá, Colombia, 210 pp.

Miserendino M. L., Casaux R., Archangelsky M., Di Prinzio C., Brand C. and Kutschker A. (2011). Assessing land-use effects on water quality, in-stream habitat, riparian ecosystems and biodiversity in Patagonian northwest streams. Sci. Total Environ. 409 (3), 612624. DOI: 10.1016/j.scitotenv.2010.10.034

Molina A., Vanacker V., Balthazar V., Mora D. and Govers G. (2012). Complex land cover change, water and sediment yield in a degraded Andean environment. J. Hydrol. 472-473, 25-35.

DOI: 10.1016/j.jhydrol.2012.09.012

Molozzi J., João M., Fuensanta J., Marques C. and Callisto M. (2012). Development and test of a statistical model for the ecological assessment of tropical reservoirs based on benthic macroinvertebrates. Ecol. Indic. 23, 155-165. DOI: 10.1016/j.ecolind.2012.03.023

Mosquera A., Martínez J. P. and Figueroa A. (2014). Microclimatic gradients in transition zones of Andean forest: A case study of Purace National Park. Sci. Res. Essays 9 (16), 703-715. DOI: 10.5897/SRE2014.5993

Mouri G., Takizawa S. and Oki T. (2011). Spatial and temporal variation in nutrient parameters in stream water in a rural-urban catchment, Shikoku, Japan: Effects of land cover and human impact. J. Environ. Manage. 92 (7), 1837-1848.

DOI: 10.1016/j.jenvman.2011.03.005

Muñoz L. E., Holwerda F., Gómez M., Equihua M., Asbjornsen H., Bruijnzeel L. A., Marín B. E. and Tobón C. (2012). Water balances of old-growth and regenerating montane cloud forests in central Veracruz, Mexico. J. Hydrol. 462-463, 53-66.

DOI: $10.1016 /$ j.jhydrol.2011.01.062

Nagendra H., Lucas R., Honrado J. P., Jongman R. H., Tarantino C., Adamo M. and Mairota P. (2013). Remote sensing for conservation monitoring: Assessing protected areas, habitat extent, habitat condition, species diversity, and threats. Ecol. Indic. 33, 45-59.

DOI: $10.1016 /$ j.ecolind.2012.09.014

Otero J. D., Figueroa A., Muñoz F. A. and Peña M. R. (2011). Loss of soil and nutrients by surface runoff in two agro-ecosystems within an Andean paramo area. Ecol. Eng. 37 (12), 2035-2043.

DOI: $10.1016 /$ j.ecoleng.2011.08.001
Ouyang W., Song K., Wang X. and Hao F. (2014). Nonpoint source pollution dynamics under long-term agricultural development and relationship with landscape dynamics. Ecol. Indic. 45, 579-589.

DOI: $10.1016 /$ j.ecolind.2014.05.025

PNUD (2010). Ruta de transición para la adaptación en el área piloto - Cuenca alta del Río Cauca: Programa Conjunto Integración de ecosistemas y adaptación al cambio climático en el macizo colombiano. 1a ed. Instituto de Hidrología, Meteorología y Estudios Ambientales. Bogotá, Colombia, 14 pp.

Recaman L. (2006). Evaluación de la oferta y demanda de la subcuenca del rio Piedras. MSc Thesis. Facultad de Educación. Universidad del Cauca. Popayán, Colombia, $120 \mathrm{pp}$.

Rojas M., Velásquez M. and Orta de Franco V. (2011). Urban agriculture, using sustainable practices that involve the reuse of wastewater and solid waste. Agricultural Water Management 98 (9), 1388-1394.

DOI: $10.1016 /$ j.agwat.2011.04.005

Ruiz D., Martínez J. P. and Figueroa A. (2015). Agricultura sostenible en ecosistemas de alta montaña. Biotecnología en el Sector Agropecuario y Agroindustrial 13 (1), 129-138.

Salman A.S., Rawi C. S., Ahmad A. H., Hamid S. A. and Siti M. N. (2011). Influence of agricultural, industrial, and anthropogenic stresses on the distribution and diversity of macroinvertebrates in Juru River Basin,Penang, Malaysia. Ecotoxicol. Environ. Saf. 74 (5), 1195-1202. DOI: 10.1016/j.ecoenv.2011.02.022

Valencia M., Figueroa A., Ruiz D., Otero J. D., Martínez J. P., Ceballos V., González D. (2014). Metodológia para el analisis de vulnerabilidad en cuencas abastecedoras de agua ante la variabilidad climática. Ingenierías Universidad de Medellín 13 (25), 29-43.

Van Oudenhoven A., Petz K., Alkemade R., Hein L. and De Groot R. (2012). Framework for systematic indicator selection to assess effects of land management on ecosystem services. Ecol. Indic. 21, 110-122.

DOI: 10.1016/j.ecolind.2012.01.012

Villamarín C., Rieradevall M., Paul M. J., Barbour M. T. and Prat N. (2013). A tool to assess the ecological condition of tropical high Andean streams in Ecuador and Peru: The IMEERA index. Ecol. Indic. 29, 79-92. DOI: 10.1016/j.ecolind.2012.12.006

Whitehead P. G., Wilby R. L., Battarbee R. W., Kernan M. and Wade A. J. (2009). A review of the potential impacts of climate change on surface water quality. Hydrol. Sci. J. 54 (1), 101-123.

DOI: $10.1623 /$ hysj.54.1.101 